\title{
Enhancement of Passive Immunity with Maternal Vaccine against Newborn Calf Diarrhea
}

\author{
Junko KOHARA, Tsunao HIRAI, Kiyokazu MORI, Hiroshi ISHIZAKI1)*, and Hiroshi TSUNEMITSU2) \\ Shintoku Animal Husbandary Experiment Station, Shintoku, Hokkaido 081, ${ }^{11}$ Department of Veterinary Microbiology, Obihiro \\ University of Agriculture and Veterinary Medicine, Inada-cho, Obihiro, Hokkaido 080, and ${ }^{21}$ Hokkaido Research Station, National \\ Institute of Animal Health, Hitsujigaoka 4, Toyohira, Sapporo, Hokkaido 062, Japan
}

(Received 1 April 1997/Accepted 1 July 1997)

ABSTRACT. The effects of a maternal vaccine against newborn calf diarrhea associated with group A bovine rotavirus (BRV), bovine coronavirus (BCV), bovine parvovirus and K99 Escherichia coli (E.coli) were examined on a beef cow-calf herd. After vaccination, serum or colostrum antibody titers to BRV, BCV and E. coli $\mathrm{K} 99$ in the vaccinated cows were significantly higher than those in unvaccinated control cows. Serum antibody titers to BRV, BCV and E. coli K99 in calves from the vaccinated cows were also significantly higher than those in calves from the control cows for 3-4 weeks after birth. These results suggested that the immunization of cows with the maternal vaccine enhanced the passive immunity levels in calves against BRV, BCV and K99 E. coli. - KEY wORDs: bovine coronavirus, bovine rotavirus, K99 Escherichia coli.

J. Vet. Med.Sci. 59(11): 1023-1025, 1997

Acute diarrhea is a common disease in newborn calves. Group A bovine rotavirus (BRV), bovine coronavirus (BCV), and enterotoxigenic Escherichia coli (E.coli) are major pathogens which cause newborn calf diarrhea [3, 6]. During the first few weeks of life, calves acquire maternal antibodies from colostrum and milk, which can exert a local protective effect against enteropathogens in the gut as passive immunity. Previous studies demonstrated that continuous feeding of colostrum from immunized cows prevented severe diarrhea and death in calves $[1,10,12,14$, 18]. In North America and Europe, various maternal vaccines against calf diarrhea to enhance antibody titers in the colostrum and milk of cows have been developed [7, $11,14,17,20]$. By contrast, there are few reports on maternal vaccination to protect against calf diarrhea in Japan. In the present study, we conducted a field trial of a maternal combination vaccine which was available in Europe and examined the enhancement of passive immunity with this vaccine.

The study was conducted with 96 beef cows (Angus, Hereford and Japanese Black) aged 2-11 years and their 97 calves at the Shintoku Animal Husbandry Experiment Station in 1994. The calves were reared on their mothers. A commercial combination vaccine (Lactovac; Hoechst, Germany) was used [20], which contained inactivated group A BRV V1005/78 [G serotype 10 (G10), P genotype 5 (P5)] and Holland [G serotype 6 (G6), P genotype 1 (P1)] strains at both titers $10^{7.5} \mathrm{TCID}_{50} / 5 \mathrm{ml}, \mathrm{BCV} 800$ strain at titer $10^{7.5}$ $\mathrm{TCID}_{50} / 5 \mathrm{~m} l$, bovine parvovirus (BPV) Haden strain at titer $10^{7.7} \mathrm{TCID}_{50} / 5 \mathrm{~m} l$ and $E$. coli- K99 pilus antigen at titer 512 $\mathrm{HU} / 5 \mathrm{ml}$. The 48 pregnant cows were inoculated subcutaneously in the side of the neck with $5 \mathrm{~m} l$ of the vaccine at 6 to 11 weeks before calving. Four weeks after

* Present address: Ishizaki, H., Animal Hygiene Laboratory, Department of Grazing Production, National Grassland Research Institute, Nishinasuno, Tochigi 329-27, Japan. the first vaccination, the second booster injection was given in the same manner. The remaining 48 cows served as unvaccinated controls. The calves from the vaccinated and control cows were observed for clinical signs once daily. Serum samples were collected from the vaccinated cows at vaccination, at calving and post-calving days 2, 7 and 28, and from the control cows at times corresponding to sampling in the vaccinated cows. Colostrum and milk samples were collected from all the cows on the day of calving and post-calving days 2, 7 and 28. Serum and feces were taken from all the calves on days 2, 7, 21 and 28 after birth. Feces were also obtained when these calves developed diarrhea.

The fecal suspensions were examined for enteric viruses by electron microscopy [2], and group A BRV was also detected by a latex agglutination test (Rotalex; Orion Diagnosis, Espoo, Finland). Virus-neutralizing antibody titers to NCDV (G6) and KK3 (G10) strains of group A $\mathrm{BRV}$ in serum and milk samples were determined by a fluorescence focus neutralizing (FFN) test with MA104 cells as described previously [9]. The virus-neutralizing antibody titers to the Mebus strain of BCV and the BF-15 strain of BPV were determined by CPE inhibition tests with HRT-18 cells and BT cells, respectively [15, 19]. E. coli K99 antibody titers were determined by a passive hemagglutination test [8]. Statistical analysis of the data was performed using the Student's $t$-test and the $\chi^{2}$ test.

Abortions and other adverse reactions were not observed in the 48 vaccinated pregnant cows. At the first vaccination, there were no differences in serum antibody titers to BRV, $\mathrm{BCV}, \mathrm{BPV}$ and E. coli $\mathrm{K} 99$ between the vaccinated and control cows. At the second vaccination, serum antibody titers to both $\mathrm{G}$ serotypes of BRV, BCV and E. coli K99 in the vaccinated cows increased and were higher than those of controls $(\mathrm{P}<0.05)$ (Table 1$)$. Colostrum antibody titers to both serotypes of BRV and E. coli K99 in the vaccinated cows were higher than those of control cows $(\mathrm{P}<0.05)$. For 3-4 weeks after birth, the calves from the vaccinated cows 
Table 1. Virus-neutralizing antibody titers to bovine rotavirus (BRV), bovine coronavirus (BCV) and bovine parvovirus (BPV), and hemagglutination antibody titers to E. coli K99 in serum, colostrum and milk of vaccinated or control cows

\begin{tabular}{|c|c|c|c|c|c|c|c|c|c|c|c|}
\hline \multirow{3}{*}{$\begin{array}{c}\text { Group of } \\
\text { cow }\end{array}$} & \multirow{3}{*}{ Pathogen } & \multicolumn{3}{|c|}{ At time of vaccination } & \multirow{2}{*}{$\begin{array}{l}\text { At time of } \\
\text { calving }\end{array}$} & \multicolumn{6}{|c|}{ At days after calving } \\
\hline & & \multirow{2}{*}{$\frac{1 \mathrm{st}}{\text { serum }}$} & \multirow{2}{*}{$\frac{\text { 2nd }}{\text { serum }}$} & \multirow{2}{*}{$-\frac{}{\text { serun }}$} & & \multicolumn{2}{|r|}{2} & \multicolumn{2}{|c|}{7} & \multicolumn{2}{|c|}{28} \\
\hline & & & & & colostrum & serum & milk & serum & milk & serum & milk \\
\hline Vaccinated & BRV & 422 & $970 *$ & $1280 *$ & $5881 *$ & $844 *$ & $320 *$ & $735^{*}$ & 53 & 557 & 26 \\
\hline Control & (Lincoln) & 368 & 279 & 184 & 1114 & 211 & 80 & 243 & 40 & 279 & 15 \\
\hline Vaccinated & BRV & 106 & $320 *$ & $640^{*}$ & $6756^{*}$ & $640 *$ & $184 *$ & $368^{*}$ & $46^{*}$ & 211 & $26^{*}$ \\
\hline Control & (KK3) & 106 & 106 & 106 & 1280 & 106 & 46 & 106 & 19 & 92 & 11 \\
\hline Vaccinated & $\mathrm{BCV}$ & 676 & $2353^{*}$ & 1261 & 6654 & 1097 & 169 & 832 & 37 & $724 *$ & 13 \\
\hline Control & $D C V$ & 338 & 676 & 549 & 1783 & 588 & 60 & 478 & 28 & 256 & 10 \\
\hline Vaccinated & BPY & 21 & 18 & 23 & 128 & 20 & 10 & 15 & 5 & 20 & 4 \\
\hline Control & DIV & 30 & 26 & 28 & 52 & 37 & 6 & 30 & 4 & 26 & 3 \\
\hline Vaccinated & K99 E. coli & 4 & $42 *$ & $104 *$ & $2353 *$ & $104 *$ & $239 *$ & $104 *$ & $30 *$ & $74 *$ & 7 \\
\hline Control & & 5 & 7 & 7 & 14 & 8 & 4 & 8 & 4 & 9 & 4 \\
\hline
\end{tabular}

* Geometric mean titers of vaccinated cows were significantly higher than those of control cows $(\mathrm{P}<0.05)$.

Table 2. Virus-neutralizing antibody titers to bovine rotavirus (BRV), bovine coronavirus (BCV) and bovine parvovirus (BPV), and hemagglutination antibody titers to E. coli K99 in serum of calves from vaccinated and control cows

\begin{tabular}{llccccc}
\hline \multirow{2}{*}{$\begin{array}{l}\text { Group of } \\
\text { calf }\end{array}$} & Pathogen & \multicolumn{5}{c}{ At days after birth } \\
\cline { 3 - 7 } & & 2 & 7 & 14 & 21 & 28 \\
\hline Vaccinated & BRV & $2941^{*}$ & $2229^{*}$ & $1940^{*}$ & $1280^{*}$ & $970^{*}$ \\
Control & (Lincoln) & 557 & 422 & 320 & 279 & 279 \\
& & & & & & \\
Vaccinated & BRV & $735^{*}$ & $735^{*}$ & $358^{*}$ & $279^{*}$ & 160 \\
Control & (KK3) & 106 & 106 & 106 & 106 & 70 \\
& & & & & & \\
Vaccinated d & BCV & $2048^{*}$ & $1552^{*}$ & $1176^{*}$ & $724^{*}$ & $588^{*}$ \\
Control & & 724 & 549 & 416 & 223 & 208 \\
& & & & & & \\
Vaccinated & BPV & 69 & 52 & 42 & 32 & 28 \\
Control & & 64 & 45 & 23 & 18 & 21 \\
& & & & & & \\
Vaccinated & K99 E. coli & $955^{*}$ & $832^{*}$ & $676^{*}$ & $630^{*}$ & $549 *$ \\
Control & & 7 & 5 & 3 & 3 & 3 \\
\hline
\end{tabular}

* Genometric mean titers of vaccinated calves were significantly higher than those of control calves $(\mathrm{P}<0.05)$.

had higher serum antibody titers to both $\mathrm{G}$ serotypes of $\mathrm{BRV}, \mathrm{BCV}$ and E.coli $\mathrm{K} 99$ compared with the calves from the controls $(\mathrm{P}<0.05)$ (Table 2$)$. This indicates that these serum antibodies in the calves were derived from maternal antibodies in the colostrum. There was no death of calves due to diarrhea; however, the morbidity of diarrhea in the calves from the vaccinated and the control cows was $56.9 \%$ and $50.0 \%$, respectively (Table 3 ). No difference was seen in either the mean age of onset or duration of diarrhea between the calves from the vaccinated and control cows. Bovine rotavirus was detected from 4 of 51 calves $(7.8 \%)$ at 14-36 days old from the vaccinated cows, and from 8 of 46 calves $(17.4 \%)$ at 2-38 days-old from the control cows. No BCV, BPV nor E.coli K99 was detected in any fecal samples.

The results of this field trial suggested that this commercial vaccine had the immunogenicity against G6 and G10 of BRV, BCV and K99 E. coli and enhanced passive immunity levels in calves, because of the high colostrum or serum antibody titers to these pathogens in the vaccinated cows. These colostrum antibody titers may be protective against BRV and K99 E. coli associated with calf diarrhea, as previous studies have described the protective antibody titers against experimental BRV and K99 E. coli challenge $[1,7,8,10,14,18]$. However, it was unclear that this vaccine was effective in the prevention of outbreaks of calf diarrhea in the field. The reason might be due to low morbidity for calf diarrhea associated with the pathogens which were used in the vaccine in the experimental period. Although serum antibody titers to G6 of BRV in the calves from vaccinated cows were high and prolonged over 3 weeks after birth, BRV-associated diarrhea was observed in some calves. The causes might be the following. Colostrum and milk antibodies are more important than serum antibodies, because of their painting effect in the gut for protection from infection [5, 12-14, 21]. In this trial, milk antibody titers to BRV decreased immediately after 2 days of calving, and those were below the levels to be protective against natural BRV infections when that milk was fed to naturally suckled calves. Also, the $\mathrm{G}$ serotype and $\mathrm{P}$ genotype of the BRVs shedding from the calves in this trial were G10 and P11 (data not shown), and this P genotype was different from the vaccine strains (P1 and P5). Other studies showed the most prevalent combination was G6P5 and P11 genotype strains which were detected more than P1 in Japan $[4,16]$. Therefore, the P11 of the BRV strain should be also available for the vaccine against BRV infection. 
Table 3. Summary of morbidity and mortality for calf diarrhea in the trial

\begin{tabular}{lcc}
\hline & Vaccianted $^{\mathrm{a})}$ & Control $^{\mathrm{b})}$ \\
\hline $\begin{array}{l}\text { No. of calves } \\
\text { No. of calves } \\
\text { with diarrhea/total (\%) }\end{array}$ & 51 & 46 \\
$\begin{array}{l}\text { No. of dead calves } \\
\text { Mean age of first onset of } \\
\text { diarrhea (day) }\end{array}$ & $29 / 51(56.9)$ & $23 / 46(50.0)$ \\
$\begin{array}{l}\text { Duration of diarrhea (day) } \\
\text { No. of calves which } \\
\text { shed bovine rotavirus/total (\%) }\end{array}$ & 0.2 & 0 \\
$\begin{array}{c}\text { No. of diarrheic calves which } \\
\text { shed bovine rotavirus/diarrheic calves (\%) }\end{array}$ & $3 / 29(10.3)$ & $7 / 23(30.4)$ \\
$\begin{array}{c}\text { No. of calves which } \\
\text { shed bovine coronavirus/total (\%) }\end{array}$ & $0 / 51(0)$ & $0 / 46(0)$ \\
$\begin{array}{c}\text { No. of calves which } \\
\text { shed K99 E. coli/total (\%) }\end{array}$ & $0 / 51(0)$ & $0 / 46(0)$ \\
\hline
\end{tabular}

a) Calves were born from vaccinated cows. b) Calves were born from unvaccinated cows.

We thank Mr. K. Takahashi of Hoechst Japan Ltd. for providing the vaccine, Mr. S. Ohashi and Mr. S. Ogino Central Research Laboratories, Nippon Zenyaku Kogyo Co., Ltd. for sensitized erythrocyte supply and Miss E. Matsumoto for technical assistance.

\section{REFERENCES}

1. Acres, S. D., Isaacson, R. E., Babiuk, L. A., and Kapitany, R. A. 1979. Infect. Immun. 25: 121-126.

2. Durham, P. J. K., Hassard, L. E., Norman, G. R., and Yemen, R. L. 1989. Can. Vet. J. 30: 876-881.

3. House, J. A. 1978. J. Am. Vet. Med. Assoc. 173: 573-576.

4. Ishizaki, H., Sakai, T., Shirahata, T., Taniguchi, K., Urasawa, T., Urasawa, S., and Goto, H. 1996. Vet. Microbiol. 48: 367372.

5. Mebus, C. A., White, R. G., Bass, E. P., and Twiehaus, M. J. 1973. J. Am. Vet. Med. Assoc. 163: 880-883.

6. Moon, H. W., McClurkin, A. W., Isaacson, R. E., Pohlenz, J., Skartvedt, S. M., Gillette, K. G., and Baetz, A. L. 1978. J. Am. Vet. Med. Assoc. 173: 577-583.

7. Myers, L. L. and Snodgrass, D. R. 1982. J. Am. Vet. Med. Assoc. 181: 486-488.

8. Ohashi, S., Shiba, F., Haga, Y., Ajito, T., Yamada, Y., Nemoto, H., and Motoyoshi, S. 1990. Bull. Nippon Vet. Zootech. Coll. 39: $40-49$.
9. Ojeh, C. K., Jiang, B. M., Tsunemitsu, H., Kang, S. Y., Weilnau, P. A., and Saif, L. J. 1991. J. Clin. Microbiol. 29: 2051-2055.

10. Saif, L., Redman, D. R., Smith, K. L., and Theil, K. W. 1983. Infect. Immun. 41: 1118-1131.

11. Saif, L. J., Smith, K. L., Landmeier, B. J., Bohl, E. H., and Theil, K. W. 1984. Am. J. Vet. Res. 45: 49-58 .

12. Saif, L. J. and Smith, K. L. 1985. J. Dairy Sci. 68: 206-228.

13. Snodgrass, D. R. and Wells, P.W. 1978. J. Am. Vet. Med. Assoc. 173: 565-568.

14. Snodgrass, D. R. 1982. Res.Vet. Sci. 32: 70-73.

15. Spahn, G. J., Mohanty, S. B., and Hetrick, F. M. 1966. Cornell Vet. 56: 377-386.

16. Suzuki,Y., Sanekata, T., Sato, M., Tajima, K., Matsuda, Y., and Nakagomi, O. 1993. J. Clin. Microbiol. 31: 3046-3049.

17. Thunber, E. T., Bass, E. P., and Beckenhauer, W. H. 1977. Can. J. Comp. Med. 41: 131-136.

18. Tsunemitsu, H., Shimizu, M., Hirai, T., Yonemichi, H., Kudo, T., Mori, K., and Onoe, S. 1988. Jpn. J. Vet. Sci. 51: 300308 .

19. Tsunemitsu, H., Yonemichi, H., Hirai, T., Kudo, T., Onoe, S., Mori, K., and Shimizu, M. 1991. J. Vet. Med. Sci. 53: 433-437.

20. Wieda, J., Bengelsdorff, H.J., and Hungerer, K.D. 1987. J. Vet. Med. B 34: 495-503.

21. Woode,G. N., Jones, J., and Bridger, J. 1975. Vet. Rec. 97: 148-149. 